\title{
Prevalence of Menopause and Menopausal Problems in Dharwad and Bagalkote Districts, India
}

\author{
Deepa Kannur* and Sunanda Itagi \\ Department of Human Development and Family Studies, \\ College of Community Science, UAS, Dharwad, Karnataka, India \\ *Corresponding author
}

\begin{abstract}
A B S T R A C T
The study deals with the prevalence of menopause and menopausal problems among women in Dharwad and Bagalkote districts. Through Self Help Groups (SHG) and door to door survey conducted along with concerned information among 480 respondents in eight villages from two districts. The women who experienced menopause for at least one year

with age ranges 35-55 years in rural and urban areas were considered for the study. The prevalence of the study found to be 44 per cent out of 9512 contacted adult women. In urban area 76-88 per cent of women attained natural menopause in Dharwad and Bagalkote districts respectively but in Bagalokte district 23.38 per cent of them attained menopause due to hysterectomy. Most common menopausal problems included were joint and muscular discomfort $(68.33 \%)$, sleep problems $(51.66 \%)$, hot flushes $(37.50 \%)$, sweating $(6.67 \%)$ and heart discomfort $(9.31 \%)$. Majority $(44.17 \%)$ of the women experienced moderate level of somatic problems in both districts. The respondents had moderate to severe level of psychological problems $(40 \%)$ and remaining 44 per cent experienced mild to moderate level of urogenital problems. There was a significant difference between menopausal problems it indicating that the women experienced more of somatic problems followed by psychological and urogenital problems. Age, education, occupation and socio-economic status of the respondents were negatively significantly related with menopausal problems. The study concluded that to overcome existing somatic, psychological and urogenital menopausal problems educational awareness and self-coping methods for rural and urban women are necessary.
\end{abstract}

\section{Keywords}

Menopause,

Somatic, urogenital and psychological problems,

Article Info

Accepted:

20 June 2019

Available Online:

10 July 2019

\section{Introduction}

Menopause is documented as a complete cessation of menstruation for a period of 1 year. Perimenopause duration is variable, and it is defined as the time of irregular periods until menopause. The natural menopausal age of a woman serves as a biomarker for subsequent disease prediction and mortality.
While earlier menopause is associated with an increased risk of cardiovascular disease and osteoporosis, it is also an important protector from breast cancer Epidemiological studies have identified that age adjusted mortality is reduced by $2 \%$ while the risk of uterine/ovarian cancer increases by $5 \%$ with each increasing year of age at menopause. Better medical and living facilities have led to 
an increased life expectancy in India, and in fact, 130 million Indian women are expected to live beyond menopause by 2015 (Gupta et al., 2019).

Termination of menstruation for more than 12 months implies menopause, which is normal physiological change experienced by almost all women of middle ages. During the menopausal transition, women may experience a variety of symptoms ranging from vasomotor symptoms to sleep and mood disturbance, lack of sexual desire, and dryness in vagina.

Many a time women are unaware of menopausal symptoms experienced by them. Worldwide natural menopause occurs between the age of 45 and 55 years. Mean age at menopause for Indian women ranges from 40.32 to 48.84 years and in developed countries from 48 to 51 years.

In 1990, there were about 467 million postmenopausal women worldwide and it is expected to rise to 1200 million by 2030 . Of these, $76 \%$ will be living in the developing countries (Patel et al., 2017). Hence the study was undertaken with following objectives,

To know the prevalence of menopause of two districts.

To assess menopausal problems among rural and urban women.

\section{Materials and Methods}

\section{Population and sample}

Menopausal women were randomly selected from Dharwad and Bagalkote city areas comprised of urban sample. Similarly women were randomly from eight villages of Dharwad and Bagalkote talukas comprised of rural sample $(\mathrm{N}=480)$.

\section{Research design}

The differential design was used with the aim to compare problems of working and nonworking women. Correlation design was used to know the inter-relationship between problems with age, education, occupation and socio-economic status of family.

\section{Tools}

The tools for the study were the self-structured questionnaire to elicit the information regarding personal information like name of the family members with their age, relationship with respondents and family income.

Menopausal problems were assessed by using menopause rating scale developed by Berlin.1992 to know the age related decline of physical and mental capacity. It consists of 11 questions divided into 3 sub scale such as psychological (items 4 to 7), somatic (items 1, 2, 3 and 11) and urogenital (items 8 to 10). The respondent has to indicate her problems with intensity of each by using 5 point likert scale. Then the responses on each item was scored as 0-4 as none to very severe. The total score was categorized to indicate menstrual problems as low (0-14), medium (15-29) and high (30-44).

\section{Results and Discussion}

The prevalence of menopause are presented in Table 1. In Dharwad 41.27 per cent of women in postmenopausal stage, whereas in 48 per cent of women in Bagalkote district in postmenopausal stage. In Dharwad majority $(87.04 \%)$ of women had natural menopause, while 12.96 per cent underwent surgical menopause. In Dharwad, majority (74.74\%) of them had natural menopause, while 25.46 per cent were underwent hysterectomy. Similar finding observed by Patel et al., (2017) 
revealed that $75-80$ per cent of the studied participants were had natural menopause 1821 per cent of the women underwent surgery in urban area.

Majority (75-90\%) of women in both districts attained menopause due to natural reasons such as aging and hormonal changes. In Bagalkote district 23 per cent of the women attained forced menopause due to hysterectomy (removal of ovaries and uterus). In-depth report indicated different causes which are depicted in Figure 1. It was reported that, 21.54 per cent of the women underwent surgery because of fibroid condition while 14.77 per cent of them had endometriosis and 10.83 per cent suffered from cysts in ovary. Only few (6.81\%) and 4.54 per cent got hysterectomy done due to polycystic ovary and blockage in uterine tube. The study was supported by Balan, 2017 that revealed that cysts and fibroids were main cause for undergoing surgery. Similar results were observed by Sangamam and Sreelakshmy (2017) reported that the most common reasons for hysterectomy were cyst (30\%), endometriosis (24\%) and fibroid (33\%).

The socio-demographic characteristics of the sample are presented in the Table 2. It is apparent from the table that the age ranged between 35 to 55 years. Majority (26-34\%) of the women aged between 46-50 years while 24-32 per cent of them were aged between 5155 years followed by 40-45 years (23-30\%) and 35-39 years (11-19\%). Half of the respondents $(50 \%)$ were homemakers while 10-30 per cent was involved in farm activities and 11-22 per cent of them worked as daily wagers and 8-16 per cent of the women were self-employment. More than half (54-58\%) of the rural women were illiterate while 37-40 per cent of the rural women completed primary school and 8-15 per cent had not attended school. Whereas among urban area, 40-56 per cent were completed primary school and 15-16 per cent of them had high school and 26-44 per cent of them had not attended school.

With respect to caste, $39-55$ per cent of the women from Dharwad district belonged to Other Backward Class (OBC) followed by 2529 per cent upper caste. Whereas in Bagalkote district, majority (44-49\%) of the women belonged to Other Backward Class (OBC) followed by 23-25 per cent who were dalits. On an average 50-70 per cent of a rural women had 3-4 children in their family, in contrast 28-38 per cent of them had 1-2 children, 39-50 per cent of them had 3-4 children in their family but 16-33 per cent of the respondents had 5-6 children in their family both in urban and rural area. SocioEconomic Status (SES) of the family assessed by Aggarwal tool according to score obtained showed that, majority $(35-43 \%)$ of the respondents belonged to lower middle SES status followed by upper middle class (20$32 \%$ ) and 15-29 per cent of them were in poor SES category in both rural and urban area of Dharwad and Bagalkote district. In all the demographic characteristics did not differ much in the two districts.

Menopausal characteristics of working and non-working are indicated in Table 3A. Nearly half $(48.75 \%)$ the working women attained menarche between 11-13 years while 42.50 per cent of non-working women had it between below 11 years and 19-29 per cent of women attained between 14-15 years. With regard to age at menopause, 38.33 per cent of working women and 35 per cent of nonworking women attained menopause between 46-50 years and 41-45 years respectively. Only 11-13 per cent of them had attained menopause between 51-55 years of age. More than half (50-55\%) of working and nonworking women had reproductive years between 21-25 years and mean age at length of reproductive years was $23.16 \pm 2.45$ years. 
Table.1 Prevalence of menopausal women in Dharwad and Bagalkote districts

\begin{tabular}{|c|c|c|c|c|c|}
\hline Districts & Locality & $\begin{array}{c}\text { Women } \\
\text { contacted } \\
(\mathbf{N = 9 5 1 2})\end{array}$ & $\begin{array}{c}\text { Menopausal women } \\
(\mathbf{n = 4 2 2 5})\end{array}$ & \multicolumn{2}{|c|}{ Type of menopause } \\
\cline { 3 - 7 } & & & & $\begin{array}{c}\text { Natural } \\
(\mathbf{n = 3 6 4 8})\end{array}$ & $\begin{array}{c}\text { Surgical } \\
(\mathbf{n}=\mathbf{5 7 7})\end{array}$ \\
\hline \multirow{2}{*}{ Dharwad } & Rural & 2020 & 922 & $853(92.52)$ & $69(7.48)$ \\
\cline { 2 - 6 } & Urban & 1600 & 1358 & $1199(88.30)$ & $159(11.70)$ \\
\hline \multirow{2}{*}{ Bagalkote } & Rural & 3290 & 696 & $639(91.81)$ & $57(8.19)$ \\
\cline { 2 - 6 } & Urban & 2602 & 1249 & $957(76.62)$ & $292(23.38)$ \\
\hline
\end{tabular}

Figures in the parenthesis indicates percentage

Table.2 Demographic characteristics of menopausal women

\begin{tabular}{|c|c|c|c|c|c|c|}
\hline \multirow{2}{*}{\multicolumn{2}{|c|}{ Characteristics }} & \multirow[t]{2}{*}{ Variables } & \multicolumn{2}{|c|}{ Dharwad } & \multicolumn{2}{|c|}{ Bagalkote } \\
\hline & & & $\begin{array}{c}\text { Rural } \\
(\mathbf{n}=120)\end{array}$ & $\begin{array}{c}\text { Urban } \\
(\mathbf{n}=\mathbf{1 2 0})\end{array}$ & $\begin{array}{c}\text { Rural } \\
(\mathbf{n}=120)\end{array}$ & $\begin{array}{c}\text { Urban } \\
(\mathbf{n}=120)\end{array}$ \\
\hline \multirow{4}{*}{\multicolumn{2}{|c|}{ Age (years) }} & $35-39$ & $20(16.67)$ & $16(13.33)$ & $23(19.17)$ & $14(11.67)$ \\
\hline & & $40-45$ & $31(25.83)$ & $28(23.33)$ & $36(30.00)$ & $34(28.33)$ \\
\hline & & $46-50$ & $38(31.67)$ & $37(30.84)$ & $32(26.67)$ & $41(34.17)$ \\
\hline & & $51-55$ & $31(25.83)$ & $39(32.50)$ & $29(24.16)$ & $31(25.83)$ \\
\hline \multirow{4}{*}{ Occupation } & Non-working & Housewife & $60(50.00)$ & $60(50.00)$ & $60(50.00)$ & $60(50.00)$ \\
\hline & \multirow[t]{3}{*}{ Working } & Farm laborers & $31(25.83)$ & $22(18.33)$ & $36(30.00)$ & $13(10.83)$ \\
\hline & & Self employed & $11(10.00)$ & $15(12.50)$ & $10(8.33)$ & $20(16.67)$ \\
\hline & & Daily wagers & $18(15.00)$ & $23(19.17)$ & 14 (11.67) & $27(22.50)$ \\
\hline \multirow{3}{*}{\multicolumn{2}{|c|}{ Education }} & High school & $10(8.33)$ & $20(16.67)$ & $15(12.50)$ & $18(15.00)$ \\
\hline & & Primary & $45(37.50)$ & $68(56.67)$ & 35 (29.17) & $49(40.83)$ \\
\hline & & Illiterate & $65(54.17)$ & $32(26.67)$ & $70(58.33)$ & $53(44.17)$ \\
\hline \multirow{4}{*}{\multicolumn{2}{|c|}{ Caste }} & Upper caste & $35(29.17)$ & $30(25.00)$ & 17 (14.17) & $12(10.00)$ \\
\hline & & $\mathrm{OBC}$ & 47 (39.17) & $66(55.00)$ & $53(44.17)$ & $59(49.17)$ \\
\hline & & Dalits & $25(20.83)$ & $15(12.50)$ & $31(25.83)$ & $28(23.33)$ \\
\hline & & Tribals & $13(10.83)$ & $9(7.50)$ & $19(15.83)$ & $21(17.50)$ \\
\hline \multirow{3}{*}{\multicolumn{2}{|c|}{ No of children }} & $1-2$ & $19(15.83)$ & $46(38.33)$ & $13(10.83)$ & $34(28.33)$ \\
\hline & & $3-4$ & $61(50.83)$ & 47 (39.17) & $87(72.50)$ & $62(51.67)$ \\
\hline & & $5-6$ & $40(33.33)$ & $27(22.50)$ & $20(16.67)$ & $24(20.00)$ \\
\hline \multirow{6}{*}{\multicolumn{2}{|c|}{ SES of the family }} & Upper High & $0(0.00)$ & $0(0.00)$ & $0(0.00)$ & $0(0.00)$ \\
\hline & & High & $9(7.50)$ & $20(16.67)$ & $11(9.17)$ & 17 (14.17) \\
\hline & & Upper Middle & $32(26.67)$ & $42(35.00)$ & $26(21.67)$ & $57(43.33)$ \\
\hline & & Lower Middle & $51(42.50)$ & $39(32.50)$ & $48(40.00)$ & $25(20.83)$ \\
\hline & & Poor & $28(23.33)$ & $19(15.83)$ & 35 (29.17) & $21(17.50)$ \\
\hline & & Very poor & $0(0.00)$ & $0(0.00)$ & $0(0.00)$ & $0(0.00)$ \\
\hline
\end{tabular}

Figures in the parenthesis indicates percentage 
Table.3A Menopausal problems among working and non-working women

\begin{tabular}{|c|c|c|c|c|c|}
\hline \multirow{2}{*}{$\begin{array}{l}\text { Sl } \\
\text { No }\end{array}$} & \multirow{2}{*}{$\begin{array}{l}\text { Menopausal problems } \\
\text { (*Multiple responses) }\end{array}$} & \multicolumn{2}{|c|}{ Rural } & \multicolumn{2}{|c|}{$\begin{array}{l}\mathrm{N}=480 \\
\text { Urban }\end{array}$} \\
\hline & & $\begin{array}{l}\text { Working } \\
(\mathrm{n}=120)\end{array}$ & $\begin{array}{c}\text { Non- } \\
\text { working } \\
(n=120)\end{array}$ & $\begin{array}{l}\text { Working } \\
(n=120)\end{array}$ & $\begin{array}{c}\text { Non- } \\
\text { working } \\
(n=120)\end{array}$ \\
\hline I & Somatic & & & & \\
\hline 1 & Hot flushes, sweating & $60(50.00)$ & $57(47.50)$ & $45(37.50)$ & $59(49.17)$ \\
\hline 2 & $\begin{array}{l}\text { Heart discomfort (unusual awareness of heart beat, } \\
\text { heart skipping, heart racing, tightness) }\end{array}$ & $12(10.00)$ & $5(4.16)$ & $8(6.67)$ & $14(11.67)$ \\
\hline 3 & $\begin{array}{l}\text { Sleep problems (difficulty in falling asleep, } \\
\text { difficulty in sleeping through, waking up early) }\end{array}$ & $42(35.00)$ & $69(57.50)$ & $62(51.66)$ & $71(59.17)$ \\
\hline 4 & $\begin{array}{l}\text { Joint and muscular discomfort (pain in the joints, } \\
\text { rheumatoid complaints) }\end{array}$ & $82(68.33)$ & $75(62.50)$ & $75(62.50)$ & $67(58.84)$ \\
\hline II & Psychological & & & & \\
\hline 5 & $\begin{array}{l}\text { Irritability (feeling nervous, inner tension, feeling } \\
\text { aggressive) }\end{array}$ & $69(57.50)$ & $63(52.50)$ & $72(60.00)$ & $67(55.83)$ \\
\hline 6 & Depressive mood (feeling down, sad, mood swings) & $66(55.00)$ & $47(39.17)$ & $54(45.00)$ & $69(57.50)$ \\
\hline 7 & Anxiety (inner restless, feeling panicky) & $43(35.83)$ & $35(29.17)$ & $38(31.67)$ & $47(39.17)$ \\
\hline 8 & $\begin{array}{l}\text { Physical and mental exhaustion (general decrease in } \\
\text { performance and concentration, forgetfulness) }\end{array}$ & $73(60.83)$ & $59(49.17)$ & $49(40.83)$ & $56(46.67)$ \\
\hline III & Urogenital & & & & \\
\hline 9 & $\begin{array}{l}\text { Bladder problems (difficulty in urinating, increased } \\
\text { need to urinate, bladder incontinence) }\end{array}$ & $7(5.83)$ & $10(8.33)$ & $12(10.00)$ & $15(12.50)$ \\
\hline 10 & $\begin{array}{l}\text { Dryness of vagina (sensation of dryness or burning } \\
\text { in the vagina) }\end{array}$ & $7(5.83)$ & $8(6.67)$ & $10(8.33)$ & $8(6.67)$ \\
\hline 11 & $\begin{array}{l}\text { Sexual problems (change in sexual desire, in sexual } \\
\text { activity and satisfaction) }\end{array}$ & $5(4.17)$ & $6(5.00)$ & $7(5.83)$ & $9(7.50)$ \\
\hline
\end{tabular}
Figures in the parenthesis indicates percentage

Table.3B Distribution of working and nonworking women by menopausal problems

\begin{tabular}{|c|c|c|c|c|c|c|c|}
\hline \multirow{3}{*}{ Area } & \multirow{3}{*}{ Occupation } & \multirow{3}{*}{ Problems } & \multirow{2}{*}{\multicolumn{3}{|c|}{ Category }} & \multicolumn{2}{|c|}{$\mathrm{N}=480$} \\
\hline & & & & & & \multirow{2}{*}{$\chi^{2}$} & \multirow{2}{*}{ r-value } \\
\hline & & & Mild & Moderate & Severe & & \\
\hline \multirow[t]{6}{*}{ Rural } & \multirow{3}{*}{$\begin{array}{l}\text { Non-working } \\
\quad(\mathbf{n}=\mathbf{1 2 0})\end{array}$} & Somatic & $25(20.83)$ & $61(50.83)$ & $34(28.33)$ & \multirow{3}{*}{$38.46^{*}$} & \multirow{3}{*}{$0.37 *$} \\
\hline & & Psychological & $50(41.67)$ & $48(40.00)$ & $22(18.33)$ & & \\
\hline & & Urogenital & $73(60.83)$ & $32(26.67)$ & $15(12.50)$ & & \\
\hline & \multirow{3}{*}{$\begin{array}{l}\text { Working } \\
(n=120)\end{array}$} & Somatic & $26(21.667)$ & $57(47.50)$ & $37(30.83)$ & \multirow{3}{*}{$41.56^{* *}$} & \multirow{3}{*}{$0.50 * *$} \\
\hline & & Psychological & $31(25.83)$ & $48(40.00)$ & $41(34.17)$ & & \\
\hline & & Urogenital & $61(50.83)$ & $36(30.00)$ & $23(19.17)$ & & \\
\hline \multirow[t]{6}{*}{ Urban } & \multirow{3}{*}{$\begin{array}{l}\text { Non-working } \\
\quad(n=120)\end{array}$} & Somatic & $40(33.33)$ & $52(43.33)$ & $28(23.33)$ & \multirow{3}{*}{$42.46^{* *}$} & \multirow{3}{*}{$0.48^{*}$} \\
\hline & & Psychological & $20(16.67)$ & $46(38.33)$ & $54(45.00)$ & & \\
\hline & & Urogenital & $55(45.83)$ & $38(31.67)$ & $27(22.50)$ & & \\
\hline & \multirow{3}{*}{$\begin{array}{l}\text { Working } \\
(n=120)\end{array}$} & Somatic & $39(32.50)$ & $57(47.50)$ & $24(20.00)$ & \multirow{3}{*}{$35.94 *$} & \multirow{3}{*}{$0.26^{*}$} \\
\hline & & Psychological & $19(15.83)$ & $53(44.17)$ & $48(40.00)$ & & \\
\hline & & Urogenital & $78(65.00)$ & $29(24.17)$ & $13(10.83)$ & & \\
\hline
\end{tabular}

Figures in the parenthesis indicates percentage *significant at 0.05 level **Significant at 0.01 level 
Table.3C Comparison of types of menopausal problems among non-working and working women

\begin{tabular}{|c|c|c|c|c|}
\hline Area & Occupation & Problems & Mean \pm SD & F-value \\
\hline \multirow[t]{6}{*}{ Rural } & \multirow{3}{*}{$\begin{array}{l}\text { Non-working } \\
\quad(\mathbf{n}=\mathbf{1 2 0})\end{array}$} & Somatic & $11.47 \pm 3.75$ & \multirow{3}{*}{$12.57^{*}$} \\
\hline & & Psychological & $8.40 \pm 2.98$ & \\
\hline & & Urogenital & $4.77 \pm 2.99$ & \\
\hline & \multirow{3}{*}{$\begin{array}{l}\text { Working } \\
(n=120)\end{array}$} & Somatic & $12.36 \pm 3.44$ & \multirow{3}{*}{$11.38 *$} \\
\hline & & Psychological & $10.48 \pm 3.12$ & \\
\hline & & Urogenital & $5.68 \pm 2.05$ & \\
\hline \multirow[t]{6}{*}{ Urban } & \multirow{3}{*}{$\begin{array}{l}\text { Non-working } \\
\quad(n=120)\end{array}$} & Somatic & $12.66 \pm 2.87$ & \multirow{3}{*}{$13.46^{*}$} \\
\hline & & Psychological & $9.60 \pm 3.12$ & \\
\hline & & Urogenital & $5.62 \pm 2.41$ & \\
\hline & \multirow{3}{*}{$\begin{array}{l}\text { Working } \\
(n=120)\end{array}$} & Somatic & $11.25 \pm 3.54$ & \multirow{3}{*}{$11.62 *$} \\
\hline & & Psychological & $10.36 \pm 2.01$ & \\
\hline & & Urogenital & $4.08 \pm 2.34$ & \\
\hline
\end{tabular}

*significant at 0.05 level

Table.3D Comparison of non-working and working women by menopausal problems

\begin{tabular}{|c|c|c|c|}
\hline Area & Occupation & Mean \pm SD & t-value \\
\hline \multirow[t]{2}{*}{ Rural } & $\begin{array}{c}\text { Non-working } \\
\quad(n=120)\end{array}$ & $21.31 \pm 5.14$ & \multirow[t]{2}{*}{$3.93 *$} \\
\hline & $\begin{array}{l}\text { Working } \\
(n=120)\end{array}$ & $26.47 \pm 4.06$ & \\
\hline \multirow[t]{2}{*}{ Urban } & $\begin{array}{l}\text { Non-working } \\
\quad(n=120)\end{array}$ & $24.82 \pm 5.90$ & \multirow[t]{2}{*}{$4.93 * *$} \\
\hline & $\begin{array}{l}\text { Working } \\
(n=120)\end{array}$ & $19.52 \pm 6.42$ & \\
\hline
\end{tabular}

Table.4 Inter-correlation among demographic characteristics of postmenopausal women

\begin{tabular}{|c|c|c|c|c|}
\hline Particulars & Age & Education & Occupation & SES \\
\hline Menopausal problems & $-0.42 *$ & $-0.26^{*}$ & $-0.30^{*}$ & $-0.29 *$ \\
\hline
\end{tabular}

*significant at 0.05 level 
Fig.1 Causes for surgical menopause

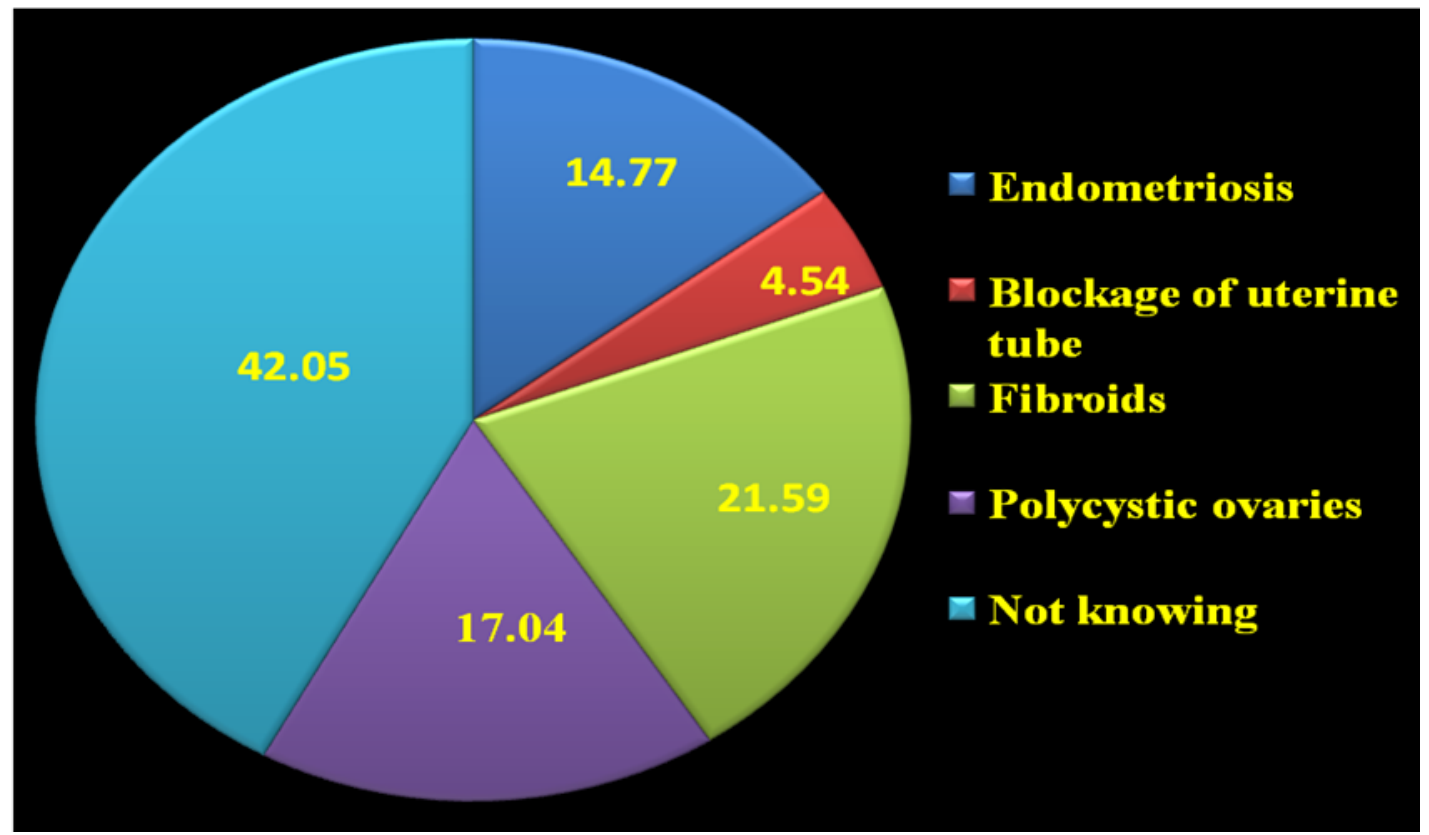

Majority (43-50\%) of the women had experienced 3-5 days of bleeding during menopause and 64 per cent had experienced 6-10 days of bleeding during menopause. Majority (40-47\%) of both working and nonworking women experienced menopausal symptoms between 36-40 years and 36 per cent of them experienced menopausal symptoms between 41-45 years of age. Similar results were observed the study conducted by Shrestha and Pandey (2017) the commonest menopausal symptoms were mood swings, irritability (80\% and 68\%) respectively followed by vasomotor symptoms like hot flushes $(42 \%)$ and night sweats $(24 \%)$.

Distribution of working and nonworking women by menopausal problems is presented in the Table 3B. In rural area, half $(50 \%)$ of the respondents experienced mild somatic problems, while 28.33 per cent were had severe and 20.83 per cent were had mild level of somatic problems. In psychological problems, 41.67 per cent of the women reported mild problems followed by moderate
(40\%) and severe level of psychological problems (18.33\%). Among urboginal problems, majority $(60.83 \%)$ of them had mild problems followed by 26.67 per cent had moderate and 12.50 per cent had severe level of uroginal problems. There was significant association and relationship between menopausal problems and occupational status. Whereas among working women, 47.50 per cent of the women reported moderate level of problems followed by 30.83 per cent and 21.67 per cent had severe and mild menopausal problems respectively.

In psychological problems, 40 per cent of the respondents had moderate menopausal problems followed by 34.17 per cent reported severe and 25.83 per cent had mild psychological problems. Half $(50 \%)$ of the women expressed mild urogenital problems followed by 30 per cent and 19.17 per cent of the women reported moderate and severe level of problems. There was highly significant relationship and association between working status and menopausal problems was observed. 
Distributions of working and non-working women by menopausal problems are presented in the Table 3B. Among nonworking rural women half $(50 \%)$ of the respondents were had moderate level of somatic problems followed by severe (28.33\%) and mild $(20.33 \%)$ level of somatic problems. Whereas among psychological problems, 41.67 per cent of them had mild level of problems while 58.33 per cent were had moderate and above moderate level of problems. Surprisingly 60 per cent of them had mild urogenital problems. Similar trend was observed in urban working women. Among working rural women, majority $(47.50 \%)$ of the women had moderate level of problems while 30.33 per cent severe and 21.67 per cent had mild level of somatic problems. In psychological problems, 40 per cent had moderate level of problems followed by severe (34.17\%) and mild level of problems $(25.83 \%)$. Half $(50.83 \%)$ of them experienced mild level of Urogenital problems. Similar trend was observed in urban non- working women. There was significant a association observed between occupational status and menopausal problems in both localities. Similarly there was significant relationship with occupation and menopausal problems of both working and non-working women. The study conducted by Salik and Kamal (2015) reported that 56-60 per cent of the both working and non-working women had somatic problems and 40 per cent of working women had psychological problems as against 15 per cent of nonworking women

The difference between menopausal problems among working and non-working in both rural and urban area are presented in Table 3C. In rural area, the mean score of somatic problems were higher than psychological and urogenital problems $(8.47 \pm 1.75>6.40 \pm 1.98$ $>3.77 \pm 1.99)$. The F-value (12.57) was found to be significant, means non-working women experienced more of somatic problems followed by psychological and urogenital problems. Similar trend was observed among rural working, urban working and nonworking women. In case of urban nonworking women, the mean score of somatic problems $(12.66 \pm 2.87)$ greater than

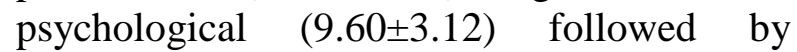
uroginal problems $(5.62 \pm 2.41)$ which is also found significant differences with the F-value of 13.46. Among working women, there was significant differences in "F" value of 11.62 in menopausal problems. The mean score of somatic problems was comparatively higher than psychological and urogenital problems $(11.25 \pm 3.54>10.36 \pm 2.01>4.08 \pm 2.34)$. It indicated that working women also experienced more of somatic problems followed by psychological and urogenital problems.

The comparison between working and nonworking women in menopausal problems are reported in Table 3D. In rural area, the working women suffered more from menopausal problems than non-working women. The mean score of working women was higher than non-working women $(26.47 \pm 4.06>21.31 \pm 5.14)$. In case of urban women, there was significant difference in ' $t$ ' value (4.93) in menopausal problems was higher in non-working women $(24.82 \pm 5.90)$ than the mean score of working women (19.52 \pm 6.42$)$.

Inter-correlation among demographic characteristics of postmenopausal women are represented in Table 4. Age, education, occupation and SES were negatively related with menopausal problems. It indicated that advance in age, educated women, women involved in occupation and women who belonged to upper SES were experienced more mild level of menopausal problems. Similar results found by Kannur and Itagi (2018) revealed that age, socio-economic 
status (SES) and education were negatively associated whereas occupation was positively associated with menopausal problems.

Rural working and urban non-working women experiencing more menopausal problems concluded there is need of education regarding self-coping and wellbeing techniques for menopausal women.

\section{References}

Balan, P., 2017, A study of menopausal symptoms in women after hysterectomy with retained ovaries. Int. J. Med. and Health Res., 3 (3): 53 -59.

Berlin, 1992, Menopause Rating Scale for to know the age related decline of physical and mental capacity. Center Epidemiol. Health Res., 16(2):16-23.

Gupta. Madhusudhan, R. S. and Sadvimani, E., 2015, Isolate cultural factors by examining the menopausal experiences. Int. J. Appl. sci., 2(8): 468-471.

Kannur. D. and Itagi, S., 2017, Influence of weight on health status and menopausal problems of rural and urban postmenopausal women. Int. J. Pure App. Bio. sci., 5(6): 1457-1464.

Patel, M., Shah, V., Kamani, H. and Sonaliya, K., 2017, Current scenario of menopause-related symptoms using menopause rating scale among middleaged women of Western India: A crosssectional study. Int. J. Med. Sci. and Pub. Health, 7(2):48-52.

Salik, R. and Kamal, A., 2015, Variations in menopausal symptoms as a function of education, employment status, and income. J. Soc. Sci, 9(2):110-116.

Sangamam and Sreelakshmy, K., 2017, Health concerns and quality of life in surgical menopause. Ind. J. Obstetrics and Gynecology Res., 4(3):292-296.

Shrestha, N. S. and Pandey, A., 2017, A study of menopausal symptoms and its impact on lives of Nepalese perimenopausal and postmenopausal women. $J$. Kathmandu Med. College, 6(19): 4-9.

\section{How to cite this article:}

Deepa Kannur and Sunanda Itagi. 2019. Prevalence of Menopause and Menopausal Problems in Dharwad and Bagalkote Districts, India. Int.J.Curr.Microbiol.App.Sci. 8(07): 2618-2626. doi: https://doi.org/10.20546/ijcmas.2019.807.322 